\title{
one nation fading to the bitter end
}

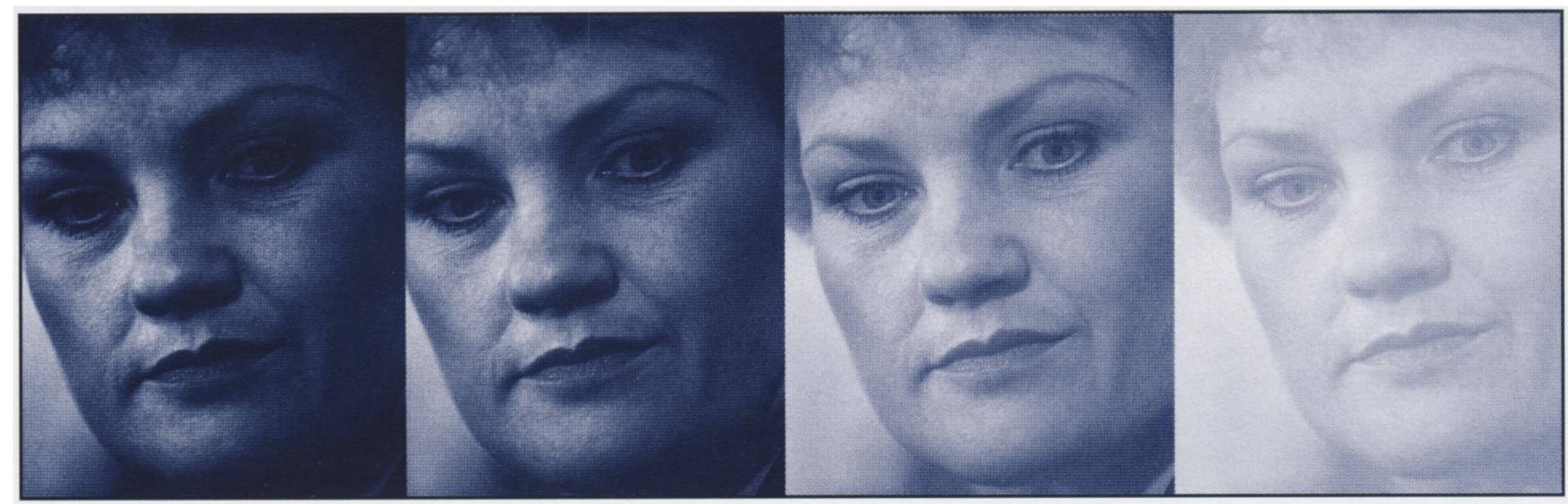

\section{Paul D.Williams}

\section{The poor result of populist right candidates in the recent Queensland by-election shows that One Nation has fallen a long way out of favour with} voters.

$\mathrm{I}$ $\mathrm{n}$ the face of a number of potentially explosive issues, the media portrayed the February by-elections in Queensland as ripe for yet another protest vote to be delivered to the major parties.

For the Beattie Labor Government, a loss in either seat would have reduced it to minority status in the Parliament and forced it to rely on the support of one or more Independents.

While most by-elections spotlight the general performance of incumbent governments, the campaigns for the state seats ofWoodridge and Bundamba - both considered "heartland" Labor electorates - quickly focused on the issue of quality parliamentary representation.

The retiring members, Bill D'Arcy and Bob Gibbs, had represented their electorates since the 1970s. But both were considered political "dinosaurs", even liabilities, and it appears each was persuaded strongly to resign: Gibbs was appointed Queensland Trade Commissioner

Paul Williams teaches in the Department of Government at the University of Queensland. to Los Angeles; and D'Arcy had been arraigned on child sex charges.

They were also accused of perennially neglecting their seats because they were "safe". It didn't help that neither Gibbs nor D'Arcy lived in, or even near, their electorates. The affluent lifestyle of each, particularly the latter, contrasted sharply with the demographic profiles of both seats, which suffered above average rates of unemployment and crime. Indeed, D'Arcy's infrequent presence in both the electorate and the Parliament led him to be dubbed "The Phantom". Indeed, opposition candidates attempted to extract further mileage by alluding to lucrative superannuation pay-outs totalling $\$ 1.5$ million. ${ }^{1}$

The Coalition Opposition urged voters to "punish" the ALP for its alleged contempt for the areas and, in Woodridge, arranged an exchange of preferences with minor candidates at Labor's expense. The issue of parliamentary representation took a sour turn when Labor candidate and former State Secretary Mike Kaiser urged Woodridge electors to support him because ministers would be less than receptive in negotiating with a nonGovernment member.

However, it was the presence of One Nation in the contest that threatened to undo Labor's chances of retaining both seats. Given that both electorates posted substantial One Nation results at the 1998 state election34.26 per cent in Bundamba and 28.39 per cent in Woodridge $^{2}$ - many assumed the ALP's vote would be once again squeezed by the appeal of disgruntled populists. The fact that Pauline Hanson's One Nation had been deregistered and that its support was to be divided between its City Council Alliance reincarnation and other populist independents appeared not to matter.

To this extent, the ALP was at pains to establish the working class credentials of each of its candidates - 
Kaiser as a boilermaker's son and Jo-Ann Miller as a coalminer's daughter, in a bid to further thwart One Nation's appeal to blue-collar voters. By all accounts, such a profiling was successful.

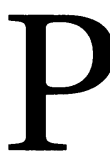

olls taken in the closing days of the campaign indicated an easy Labor win in Bundamba and a tight result in Woodridge where up to a third of the electorate remained undecided. ${ }^{3}$ The results proved ALP concerns over rancorous preference deals to be unfounded. Both Labor candidates won on primary votes and, more significantly, with Bundamba's Miller attracting an almost unprecedented swing to the Beattie Government of more than 9 per cent. ${ }^{4}$

But perhaps of greater note were the results posted by the Liberals and candidates formerly with Pauline Hanson's One Nation party. In Bundamba, the Liberals' Michele Cole attracted only 14.85 per cent while the two erstwhile One Nation candidates drew a total of 18.34 per cent $^{5}$, a figure half its 1998 result. The results in Woodridge proved even more astonishing where Liberal Irene Allen set a record low in attracting only 8.91 per cent of the vote and where ex-One Nation member Gary Wilkins scored a mere 1.83 per cent, a total lower than that of pro-cannabis campaigner Nigel Freemarijuana. ${ }^{6}$

It is fair to say that the Woodridge and Bundamba byelections provide potent lessons for both Queensland and federal politics. Locally, they show Premier Beattie is travelling well with the electorate and in control of the state political agenda. The Queensland Labor Government's regional cabinet meetings seem to have been successful in assuaging at least some rural grievances.

This is something that the federal ALP could well take note of. If, as many pundits predict, the next federal election will be won and lost in the bush, then Opposition Leader Kim Beazley would be wise to plan a comprehensive rural campaign strategy.

Also the elections show that the Queensland Opposition, particularly the Liberal Party, is facing a grave crisis of identity and public credibility. Given the campaign uncovered substantial anecdotal evidence of fastgrowing concerns over the GST's implementation, the federal Liberal Party can take this as a warning of the protest it may face down the track.

But perhaps the most puissant lesson thrown up by the by-election results are those for One Nation. Given the potentially flammable circumstances of the by-elections and the fact that much electoral discontent is yet to subside, it's remarkable that the ex-One Nation candidates performed so poorly only 18 months after their initial flourish of success.

Certainly, One Nation has suffered a number of setbacks since it burst onto the scene in 1997, riding a wave of support for minor parties and independent candi- dates which had begun to swell at the 1990 federal poll. Campaigning on zero-net immigration and reductions in government spending in such areas as aboriginal affairs and the arts, One Nation, under Pauline Hanson, redrew the electoral landscape by winning eleven seats and 23 per cent ${ }^{7}$ of the vote in the 1998 Queensland state election and 8.99 per cent ${ }^{8}$ of the vote and one Senate spot at the subsequent federal election.

But as early as late 1998 cracks began to appear. One Nation MLA Charles Rappolt resigned his seat and subsequently lost the by-election to Labor enabling it to regain its parliamentary majority. The party's hierarchy ignored moves by One Nation members to democratise its organisational structure and to make its pecuniary interests transparent. Five One Nation MLAs resigned from the party in February last year to sit as Independents, with one subsequently forming his own organisation, the Country Party.

That August, Justice Aitkinson of the Queensland Supreme Court found that the party did not have the requisite 500 members and had therefore been registered fraudulently (to date, One Nation remains deregistered in Queensland with $\$ 500,000$ in public election funding yet to be returned). The five remaining One Nation MLAs attempted to regroup under a "Queensland One Nation" banner, a move that incited the wrath of Hanson and David Oldfield. In annoyance, those remaining MLAs also resigned and, since December, they too have sat as Independents.

Moves are underway, however, for the remnants of Pauline Hanson's One Nation to regroup under the sobriquet of the City-Council Alliance (CCA). New South Wales MLC David Oldfield and Queensland Senator Len Harris are, therefore, the party's only remaining parliamentarians. To add insult to injury, police in January 2000 raided the Sydney and Ipswich offices of One Nation and seized financial and membership documents detailing the party's assets. By any measure, One Nation is some way below its peak.

If the populist right is now failing in seats with long histories of poor representation and high rates of unemployment and crime - seats seemingly tailored for One Nation support - then it is not so far-fetched to conclude that One Nation is an exhausted force in both Queensland and federal politics.

Moreover, as One Nation has become representative of the "disgruntled" vote, so integral to the success of minor parties in the 1990s, it can be further surmised that minor party and Independent support has peaked and that the major parties, in the medium term, can expect a resurgence in their primary vote. But the extent of such resurgence depends on the major parties' abilities to circumvent future public angst. As One Nation has learned, a party's credibility depends not on rhetoric but on deeds. 


\section{references}

\section{democrats}

1. SMH 16 February 2000; Australian 8 February 2000.

2. J.Warhurst (ed), Keeping the Bastards Honest: The Australian Democrats' First Twenty Years, Allen and Unwin, Sydney, 1977.

3. Senator A. Bartlett, A Perspective on the Australian Democrats 1998 Cam paign, February 1999, to be published in M.Simms and J. Warhurst (eds), Howards's Agenda: The 1998 Federal Election, University of Queensland Press, St. Lucia, 2000.

4. SMH 2 December 1999

5. Dr. M. Macklin, State of the Party, National Conference Speech, January 2000.

6. G. Ryle, "Behind the Party Girl", SMH, 8 January 2000.

7. Senator M. Lees, Speech by the Parliamentary Leader, Australian Democrats' National Conference, January 2000, p. 4

\section{censorship}

1 The legislation was enacted as the Broadcasting Services Amendment (Online Services) Act 1999 (Cth), which introduced a new Schedule 5 to the Broadcasting services Act 1999 (Cth).

2 This point was first made by Lawrence Lessig: see, for example, Lawrence Lessig, Codes and Other Laws of Cyberspace (Basic Books, 1999).

3 See JM Balkin, Beth Simone Noveck and Kermit Roosevelt, "Filtering the Internet: A Best Practices Model" in Jens Waltermann and Marcel Machill (eds) Protecting Our Children on the Internet: Towards a New Culture of Responsibility (Forthcoming, Bertelsmann Foundation, 2000).

4 Andrew Shapiro has referred to this as "oversteer", meaning too much personal control: see Andrew L Shapiro, The Control Revolution (Public Affairs, NewYork, 1999) pp 124-132.

\section{US elections}

Mondale, Walter F. (1975). The Accountability of Power: Toward a Responsible Presidency (New York: David McKay).

Polsby, Nelson W. (1983). Consequences of Party Reform (New York: Oxford University Press).

\section{poor state of affairs}

Argy, F. (1998). Australia at the crossroads: Radical free market or a progressive liberalism? St. Leonards, NSW: Allen \& Unwin.

Budget '99: Details, reactions, forecasts. (1999, May). The Age, pp. 1-8.

Chapman, B., Junankar, P., and Kapuscinski, C. (1992). Long-term unemployment: Projections and policy. Canberra: Australian National University.

Gauthier, D. (1961). Morality and advantage. Philosophical Review, 76, pp 460-75.

Gregory, B., and Sheehan, P. (1998). Poverty and the collapse of full employment. In R. Fincher, and J. Nieuwenhuysen, (Eds.), Australian poverty: Then and now, 103-126. Melbourne: Melbourne University Press.

Hawke, B. (1994). The Hawke memoirs. Melbourne: William Heinemann Australia.

Jordan, B. (1996). A theory of poverty and social exclusion. Cambridge: Polity Press.

King, A. (1998). Income poverty since the early 1970s. In R. Fincher, and J. Nieuwenhuysen, (Eds.), Australian poverty: Then and now, 71-102. Melbourne: Melbourne University Press.

Mackay, H. (1995). Reinventing Australia: The mind and mood of Australia in the 90 s. Sydney: Angus \& Robertson.

Pusey, M. (1990). Economic rationalism in Canberra: A nation building state changes its mind. Cambridge: Cambridge University Press.

Rogers, K. (1997). Self-interest: An anthology of philosophical perspectives. NewYork and London: Routledge.

Singer, P. (1995). How are we to live? Ethics in an age of self-interest. Melbourne: Mandarin.

\section{one nation}

1 The Courier-Mail, 4 February, 2000, p. 4.

2 ECQ, Queensland Election 1998, pp.66, 218.

3 CM Poll, The Courier-Mail, 4 February, 200, p. 1.

4 In Bundamba, Miller attracted 57.24 per cent of the primary vote; in Woodridge, Kaiser won with 50.78 per cent. See ECQ http://www.ecq.qld.gov.au/

5 Ibid.

6 Ibid.

7 ECQ, Queensland Election 1998 Statistical Returns, Electoral Commission Queensland, Brisbane, 1998, p. 34.

8 AEC, Electoral Pocket Book, p.78.

\section{croatia}

1 For a list of those in attendance and the low level of prominence of most of the delegations see the special edition of the Croatian Weekly, vol. 2 , No. 96 (17 December 1999), p. 3.

2 The HSLS and the SDP make up the so-called 'large coalition'. Under their coalition agreement, Racan was to become Prime Minister, and Budisa was to run for President. Mesic's surprise victory in the 7 February runoff disrupted these plans and may become a cause of friction in the operations of the new government and its relations with the President.

3 For a good comparison of their personal styles see their pre-election confrontation in the editorial offices of the Croatian opposition periodical Feral Tribune. 'Izravno suceljavanje Predsjednickih kandidata u redakciji Tribunea: Budisa vs. Mesic', No. 750, 31 January (sjecnja) 2000 [internet edition] http://www.feral-hr.com/latin2/novi_broj/obracun.html

4 See, for example, the favourable reference to 'President Stipe' in the Bosnian daily Oslobodjenje: Rasim Cerimagic, 'U Zizi: Predsjednik Stipe', Oslobodjenje online evropsko izdanje . 8 February 2000. URL www.oslobodjenje.com.ba .

5 'New Croatian President Supports Return of Serb Refugees', Central Europe Online, 11 February 2000. http://www.centraleurope. com/news.php3?id=133449 .

6 'Croatian President Wants To Testify Against Milosevic', Central Europe Online, 11 February $2000.4 \mathrm{http} / / /$.centraleurope.com. news. php3?id=133104

\section{left turns}

1 'Except as traditional party labels I use 'Left' and 'Right not for forms of government but for attitudes to equity: 'Right' means wanting present 0 greater inequalities, 'Left' means wanting to reduce them." Hugh Stretton, Capitalism, Socialism and the the Environment, Cambridge University Press, 1976, Cambridge (See also, Hugh Stretton, Political Essays, Georgian House, 1987, Melbourne.)

2 See David Stove, Anything Goes: Origins of the Cult of Scientific Irrationalism, Macleay Press, 1989, Sydney (first published under a differen title in 1982); Keith Windschuttle, The Killing of History, Macleay Press, 1994, Sydney; Alan Sokal and Jean Bricmont, Intellectual Impostures, Profile Books, 1998, London.

3 See John Newsinger "The American Connection: George Orwell, 'Literary Trotskyism' and the New York Intellectuals" (1999) Vol 64, Labour History Review, p.23 and more generally, Alan M. Wald, The Responsibility of Intellectuals, Humanities Press, New Jersey, 199; much has been written about the evolution of anti-Stalinists leftists, becoming Cold Wa warriors of the 1950's. One polemical assertion of apostasy is to be found in James P. Cannon, Notebook of an Agitator, Pathfinder Press, NewYork, 12958, pp. 158-163.

4 Michael Ignatieff, "Ascent of Man" (1999) Prospect, October, p.28 